\title{
Public Accounting Firm Characteristics: Their Importance To Students And Discussion By Recruiters
}

James Schmutte, (E-mail: Jschmutt@bsu.edu), Ball State University

\begin{abstract}
This was a survey-based study of the importance that students attach to various employer qualities and the extent that public accounting recruiters discuss such qualities. Attitudinal differences among students with different academic credentials and differences in the structure of recruiting interviews by various sized public accounting firms were the focus of the study. The data were collected from 106 accounting students and 63 recruiters. Before the beginning of the fall campus interviewing period, students rated the importance of 36 employer characteristics and recruiters reported to what extent they discussed the characteristics during the recruiting process. In general, no differences were noted among students of varying academic credentials. Significant differences, however, were noted in the level of discussion by recruiters from firms of varying size. The extent that recruiters from the various sized firms discussed the characteristics was compared with the student perceived importance. The extent that the national firm recruiters discussed the characteristics most closely matched the student importance ratings, and the discussion by the local firm recruiters least matched the student ratings.
\end{abstract}

\section{INTRODUCTION}

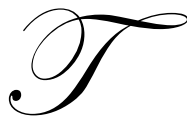

he accounting profession and individual firms, in particular, continue to face the major staffing issue of recruiting students (Fuller, 1998; Telberg, 1999; Covaleski, 1999; Albrecht \& Sack, 2000). The employment interview remains the central element in the student's entry into public accounting (Higgins, 1989; Rosenberg \& Nadolny, 1995). Public accounting firms need qualified staff, and students seek employment in firms that will meet their personal and professional needs. The employment interview process is the forum in which the student and the recruiter exchange the information that each considers relevant to their respective employment decision.

This study focuses on the recruiting interviews of public accounting firms and the extent that they meet the informational needs of student candidates. The paper investigates the perceived desirability of various employer characteristics by students. The information content of the recruiting interview is examined and compared to the informational needs of student candidates. Lastly, recruiting interviews of various sized public accounting firms are compared and assessed for their ability to meet the informational needs of students.

\section{THE EMPLOYMENT INTERVIEW PROCESS}

Porter et al. (1975) describe organizational recruiting as an attraction-selection process. The recruiter comes to the interview seeking to identify students possessing the qualities that the firm considers indicative of future success. Students enter the recruiting process seeking employment in firms that possess the attributes they value. Simultaneously, students and recruiters attempt to present themselves, respectively, as qualified candidates and favorable employment options. Accordingly, the interview includes two sets of information. One is employer specific, and the other is student related. The interview includes the two participants who perform dual roles as information providers and gathers. 
The interview process, however, can create conflicts between the student and recruiter (Porter et al., 1975). In their efforts to make themselves more attractive, each may provide incomplete or misleading information that hampers the selection process. A legacy of these conflicts is a mismatch between the student and the firm that can ultimately lead to unwanted staff turnover.

If the interview process is to be successful and potential conflicts minimized, each party should attempt to satisfy the informational needs of the other while gathering information relevant to its unique employment decision. The public accounting recruiter, however, typically controls the informational flow during the interview. Most recruiters utilize a structured style and approach the interview with a planned agenda (Higgins, 1989; Rosenberg \& Nadolny, 1995).

Contemporary recruiting research recommends the content of the interview include Realistic Job Previews (RJP) (Wanous, 1992; Roth \& Roth, 1995; Morgan \& Smith, 1996; Rosse \& Levin, 1997). By providing an accurate and representative overview of both the strengths and limitations of the position and organization, RJP results in employees who are less likely to quit. Firms engaging in RJP often discover that a job attribute that is considered positively by one person might be viewed negatively by another, and vice-versa. The candidate's perception of the attribute is not the issue. The inherent value of RJP is letting the applicant clearly understand what the position entails and requires. The goal is to allow the applicant to make a better informed employment decision.

Firms are encouraged to implement RJP early in the recruiting process to allow for self-selection on the part of the candidates. The Accounting Education Change Commission (AECC, 1993) proposed that recruiters adopt a RJP-style approach when dealing with students about to enter the profession. This study focuses on student perceptions of employer characteristics and the extent those characteristics are discussed by public accounting recruiters.

\section{PRIOR RESEARCH}

Research relative to student perceptions of the recruiting process with public accounting firms consists of two groups. The first group represents studies focusing on student perceptions of the desirability or importance of various employer characteristics. The work of Posner (1981), Scott et al. (1985), Yunker et al. (1986), Kochanek and Norgaard (1985), Lathan et al. (1987), Reed and Kratchman (1989), Larkin and Ragan (1991), Carcello et al. (1991), and McMillan, et al. (1994) represents this group. In general, these studies found that students assign greater importance to various characteristics than recruiters realize, value future earnings and promotion possibilities, and consider larger firms more likely to contain both positive and negative employer characteristics.

The second group includes studies concerning student perceptions of recruiters and recruiting techniques. The work of Posner (1981), Scott et al. (1985), Lathan et al. (1987), Fein and Krzystofik (1989), McMillan et al. (1994), and Beard (1998) reflect this area of study. Students, in general, have mixed feelings concerning the effectiveness and credibility of recruiters and consider the recruiting process unsatisfactory and lacking in objectivity when evaluating candidates. Students, however, consistently rank recruiters as useful and influential sources of information when making employment decisions. Pre-interviewing activities by firms and other sources of information are considered of limited value and influence (McMillan et al., 1994; Larkin \& Ragan, 1991).

Although research concerning the recruiting process has been extensive, several important questions remain unanswered. First, limited attempts have been made to determine the perceptions of student sub-groups. Categorizing students by their "recruitability" has not been investigated. Public accounting firms seek students who possess certain characteristics; an understanding of the employer qualities valued by these students would be useful to recruiters. Second, the content of the recruiting interview has not been addressed. Research has found that recruiters are a significant source of information for students seeking entry-level positions in public accounting. However, the extent that recruiters satisfy the informational needs of student candidates has not been investigated. Third, the few studies that have incorporated recruiters have been limited to representatives from the Big- $8 / 5$ accounting firms. Assessing the recruiting process of various sized public accounting firms has not yet been addressed. 


\section{CONTRIBUTIONS TO IMPROVE THE RECRUITING PROCESS}

Accounting faculty and practitioners share an interest in improving the transition of students into the work force. Accounting faculty have a responsibility not only to technically prepare students for careers in accounting but also to assist them in making initial employment decisions (AAA, 1995).

Accounting firms face the pressures to both attract and retain competent entry-level personnel. In the quest to alleviate staffing needs and to attract students, the content of the recruiting interview may not satisfy the informational needs of students.

Accounting faculty are often approached by students who question the requirements and demands of various employer types as well as the information furnished by recruiters. Students consider their accounting professors as a source of information about public accounting (DeZoort et al., 1997). Accounting faculty must play a greater role in the recruiting process and have an understanding of the qualities that students desire in an employer and the nature of the information that recruiters are providing (AAA, 1995).

Recruiters also have a responsibility to assist students in their entry into the accounting profession. Because of the negative early experiences of students entering the profession and the number of young professionals leaving public accounting, the AECC called for employers, students, and faculty to develop a better understanding of the accounting environment (AECC, 1993). The declining accounting student population and the continuing demand for entry-level staff have increased the importance of the recruiting process for accounting firms. By better understanding the employer-related information valued by students and examining the content of the recruiting interview, subsequent employment-related conflicts might be reduced or minimized.

\section{RESEARCH QUESTIONS}

This study focuses on research questions related to possible differences in student attitudes towards employers, the content of the recruiting interview, and the effectiveness of the recruiting interview in meeting student informational needs.

Research has shown that one of the keys to recruiting successfully and reducing staff turnover is effective communication during the attraction-selection process. Reigle and Meinert (1991) point out that the effort to attract the "best and brightest" has many facets, and recruiters should have an appreciation of the candidate's perspective of what is considered important. If public accounting firms know what the better student candidate values, firms could restructure their interviews, if necessary, and ultimately improve staff retention. Accordingly, the following question is proposed.

Question \#1: Do accounting students of differing "recruitability status" share the same opinions as to the importance of various employer characteristics when evaluating public accounting firms as potential employers?

The accounting literature has discussed the importance of addressing "quality of life" and work-related issues during the recruiting process and the need for firms to adopt an RJP approach (Roth \& Roth, 1995; Satterfield, 1991; Nelson, 1989). The AECC (1993) endorsed this concept and encouraged practitioners to communicate more accurately and fully early employment experiences and never withhold information necessary to a reasonable appreciation of facts presented.

A perception held by many in the academic community is that the statements made at the national level by public accounting firms and professional groups do not always correspond with the actions taken by local offices or individual firms (AAA, 1995). In order for accounting faculty to meet their responsibility to assist students, who are selecting an entry path into the accounting profession, they must have an understanding of the content of contemporary public accounting recruiting interviews. To better understand the depth and breadth that public accounting recruiters discuss certain employer characteristics, the following question is proposed. 
Question \#2: How much do public accounting firm recruiters discuss various employer characteristics when interviewing college students for entry-level staff positions?

Prior studies concerning the recruiting practices of public accounting firms have failed to address the possibility that such practices may vary across different sized firms. Practitioners in small and medium sized accounting firms have expressed concern that the larger national firms have an advantage in attracting and recruiting student candidates. Practitioners associated with smaller firms often attribute this recruiting success to the national firms' size and ability to use their resources to develop closer associations with universities and accounting faculty (Craig, 1990). Without first ascertaining that the content and balance of the recruiting interviews are the same for all firms, such assertions are unfounded speculations. These factors lead to the following question.

Question \#3: Do recruiters from different sized public accounting firms differ in how much they discuss various employer characteristics when interviewing college students for entry-level staff positions?

If some firms have greater success in recruiting accounting students, the content and structure of their interviews may be a contributing factor. The better a firm is able to meet the student's informational needs, the more likely the reduction of the attraction-selection conflicts arising during the recruiting process. For purposes of analysis, an interview is considered to meet the student's informational needs if the content and emphasis of matters are consistent with the level of importance the student assigns the employer characteristics. The following question focuses on whether the recruiting interviews of different sized public accounting firms are meeting student informational needs.

Question \#4: Are the recruiting interviews of different sized public accounting firms equally meeting the informational needs of accounting students?

\section{METHOD}

\section{Subjects}

Subjects participating in this study were accounting students and public accounting firm recruiters as described. ${ }^{1}$ Each groups is discussed below.

Students

Students who were enrolled in senior-level accounting courses at a Midwest university participated in the study prior to the start of the fall on-campus interviewing period. All students were in the final stages of their accounting course work and were considered by public accounting recruiters as members of the year's graduating class.

The university's undergraduate enrollment is 17,500 and includes approximately 250 junior and senior accounting majors. According to a recent national survey of 231 accounting programs, the university and its accounting program rank, in terms of enrollments, in the top 12 percent and 15 percent respectively (Duncan \& Schmutte, 2000). At the time of the survey, the school's accounting department included an undergraduate program; however, a masters program has subsequently been added in response to the 150-hour education requirement. The university's business school and the accounting program are each accredited by the American Assembly of Collegiate Schools of Business.

The Accounting Department sponsors two student organizations, a Beta Alpha Psi(BAP) chapter (which has academic eligibility requirements) and an Accounting Club (which is open to all students). Both organizations are extremely active and sponsor weekly professional meetings that featured speakers representing a variety of accounting employers and positions. The intent of both organizations is to expose students to the career alternatives available to accounting graduates. Accordingly, no one type of employer or career path dominates the programs. On 
several occasions, recruiters from the national firms stated that they had to "work harder" when recruiting at the school, and representatives from the non-national firms commented that they were not at a recruiting disadvantage.

The school has a limited internship program. Approximately 13 percent of the students have an internship typically in a corporate setting during the summer between their junior and senior years. Because of the nature of the school's internship program, students without an internship experience are not at a recruiting disadvantage. The public accounting firms focus their recruiting efforts on all students, regardless of internship experience, in the fall semester.

The students were surveyed during the fall semester before the start of the on-campus recruiting interviews. The survey instruments were distributed and completed during a class meeting. The researcher was confident that the students worked independently and complied with the instructions.

Students were categorized according to their "recruitability" for entry-level positions in public accounting. Recruitability was defined according to the student's grade-point-average (GPA) and affiliation with the Beta Alpha Psi chapter. These quantifiable criteria have been identified by Pasewark et al. (1988) and Dinius and Rogow (1988) as factors used by public accounting firms to pre-screen student candidates.

Prior internship experience was not considered a factor for determining a student's recruitability status for several reasons. As stated earlier, due to the limited size of the school's internship program, students without an internship were not at a recruiting disadvantage. Second, prior research suggests that accounting firms primarily use internships as part of their recruiting strategy rather than as a candidate screening criteria (Donelan, 1999; Meeting and Bakale, 1996; and Siegel and Rigsby, 1988). Likewise, Siegel and Rigsby (1988) found that no differences in the GPAs of accounting staff regardless of their internship experiences.

Students with a GPA greater than 3.5/4.00 and who were members of Beta Alpha Psi were considered the "prime candidates." Students with a GPA greater than 3.5/4.0 but who were not members of Beta Alpha Psi and those with a GPA between 3.00/4.00 and 3.5/4.00, regardless of their Beta Alpha Psi affiliation, were considered "average candidates." Students with a GPA less that 3.00/4.00 were classified as "poor candidates." The subsequent success of each group in securing on-campus interviews with public accounting firms was used to verify the classification scheme.

\section{Recruiters}

Recruiters representing 34 public accounting firms participated in the study. The firms were selected based on their recruiting experience at the school. A contact person at each firm was sent a number of survey instruments (and return envelopes) to be distributed to colleagues who participated in the firm's recruiting process. The contact person was specifically instructed to include personnel who participated in both the on-campus and in-office phases of the firm's recruiting process. The number of survey instruments sent to each firm was based on the size of the firm (or its local office, in the case of the national and regional firms). Forty-three firms were surveyed from which recruiters representing 34 firms responded (79 percent firm-response rate).

One hundred and nineteen survey instruments were mailed to the 43 firms from which 63 usable responses were received (53 percent recruiter-response rate). Each participant was instructed to work independently and to return the survey instrument. The possibility of a non-response bias was tested by an ANOVA comparison of the early and late respondents. The analysis did not indicate any significant between-group differences in response patterns.

\section{Survey Instrument}

Both student and recruiter participants received a questionnaire that randomly listed 36 employer characteristics. The employer characteristics were found in earlier studies (Posner, 1981; Lathan et al., 1987; Larkin \& Ragan, 1991; McMillan et al., 1994; Hermanson et al., 1995) to be important employer attributes. Characteristics 
not addressed in earlier studies were also included to reflect the changing profile of the work force. The added characteristics focused on the work place and meeting the needs of dual-career couples and working parents.

The recruiter version of the survey asked the respondent to rate, on a 5-point scale, the extent each variable was discussed with students when recruiting for entry-level positions. The recruiter questionnaire specifically stipulated that the participants were to include both on-campus and in-office interviews with students.

The student version of the survey asked the respondent to rate, on a 5-point scale, the importance he or she attached to each characteristic when evaluating a public accounting firm as a prospective employer. The questionnaires also requested demographic information from each subject.

\section{Statistical Measures}

Data analysis consisted of determining the representativeness of the sample groups and identifying the structural constructs among the subjects' responses. Two-group and multiple-group univariate analyses of variance (ANOVA), utilizing a one-way design, were used in analyzing the research questions. For each ANOVA analysis, the independent variable was defined as membership in either a student or recruiter group, as appropriate, with the dependent variable defined as the rating assigned to a specific employer characteristic. Scheffe' post-hoc tests complemented the univariate analyses.

For discussion purposes, the 36 employer characteristics were grouped into six subsets. Collectively, the sets correspond to the Existence, Relatedness, and Growth needs (E-R-G) identified by Alderfer (1972). The Existence need is reflected in the set of compensation characteristics that captured the employer characteristics associated with salary and compensation matters as well as future earnings. The personal, impact, and atmosphere sets correspond to the Relatedness need. These three sets reflect the employer characteristics that correspond to the work place environment and its demands that may affect the student's ability or opportunity to interact with others and fulfill roles within and outside the workplace. The technical development and professional development sets capture the Growth need. These two sets are associated with the employer characteristics that influence the student's ability to develop both technically and professionally.

\section{ANALYSIS}

A preliminary step in the data analysis was to determine the reliability and consistency of the participants' responses. Application of Cronbach's alpha to each subject group yielded reliability coefficients ranging between 0.87 and 0.93 . These were considered indicative of internal consistency of responses.

\section{Students}

A total of 106 senior accounting students participated in the study prior to the start of the on-campus recruiting period. The study's participants represented 83 percent of the department's graduating class of 127 students. TABLE 1 reports the demographic make-up of the graduating class as well as the participating student group. The gender mix of the students is balanced and comparable to that reported by Nelson and Vendrzyk (1996). The group's academic performance, grade-point distribution, and affiliation with the student organizations are also comparable to those noted by Nelson and Vendrzyk (1996).

The number of students classified as "prime candidates" is not consistent with the number reporting a grade point average greater than 3.50. This inconsistency is due to the lack of Beta Alpha Psi participation of some academically strong students. The school's Beta Alpha Psi chapter is very active and regularly earns "Superior Chapter" recognition. Students joining the chapter are expected to participate fully and to meet their membership responsibilities. Accordingly, some students who are academically qualified do not join due to the time commitment associated with membership. 
TABLE 1 Student Characteristics

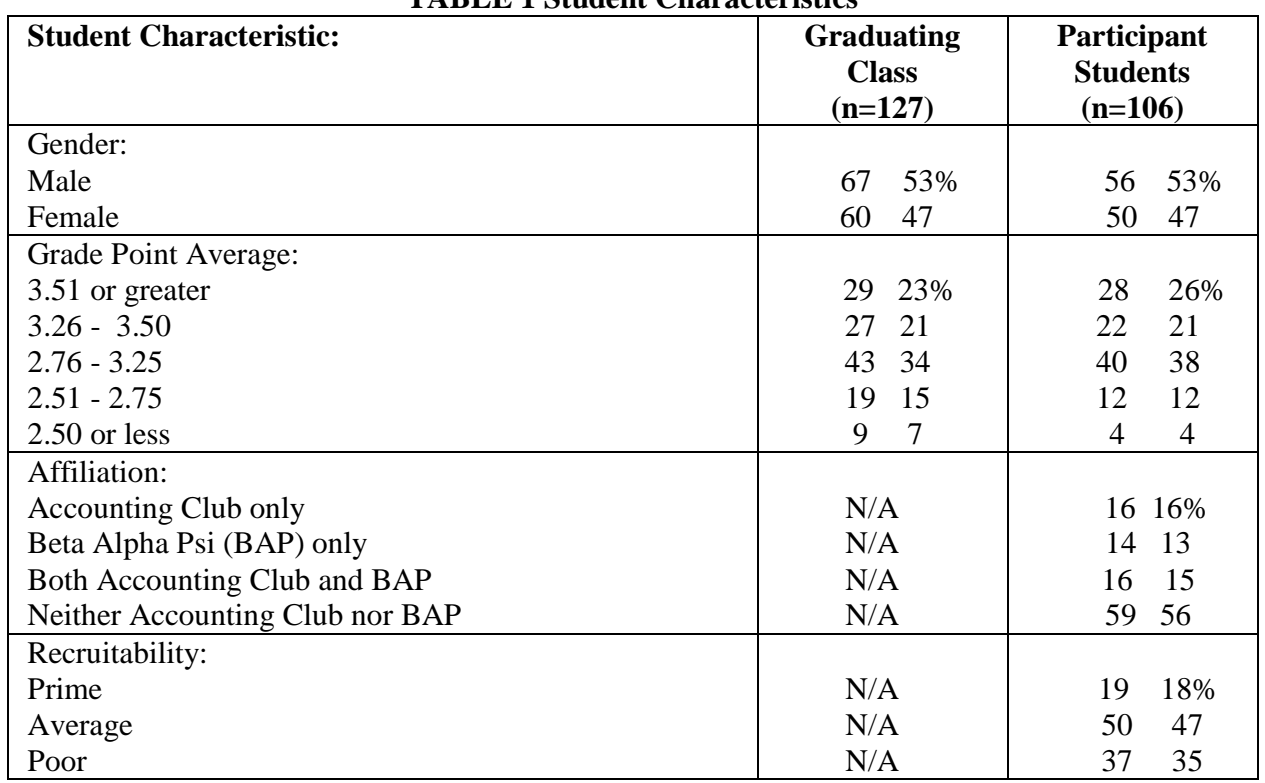

N/A - data not available

The subsequent on-campus interviewing experiences of the student participants supported the recruitability classification of the students. All on-campus interviews are coordinated through the school's Career Center. Prior to the start of the interview period, the Career Center posts a list of the public accounting firms that will be interviewing on campus. As a pre-screening technique many of the firms stipulate that the student must possess certain credentials. Only students who meet the firm's posted requirements are allowed to sign-up and leave a copy of their resume. Following the posting period, the Career Center forwards the resumes to the firms who apply their internal criteria and select the students they wish to interview.

Table 2(Panel A) reports the on-campus interviewing experiences of the graduating class, in general, as well as data relevant to the students participating in the study. Twenty-one public accounting firms interviewed oncampus during the fall period. This resulted in 1,201 student interview-requests (the interview-request figure includes multiple counts, as each student could request an interview with more than one firm). Public accounting firms selected 67 students for on-campus interviews of which 54 participated in the study.

There are several possible explanations for why some students do not participate in the on-campus interviews with public accounting firms. For example, students may have already secured employment, may plan to attend graduate school, may expect to relocate to another part of the country, or desire a career in other than public accounting. However, the overriding reason approximately one-half of the graduating class did not participate in the on-campus interviews is the nature of the selection process: academic performance is a primary factor used by public accounting firms to screen applicants.

Data were not available to match an individual student's interview requests and subsequent selection by the accounting firms. However, a statistical comparison of the GPAs of the students grouped by their participation in on-campus interviews indicated a statistically significant difference (Chi-square, $p<0.05$ ). Students with higher GPAs (greater that 3.0/4.0) were more likely to have been selected for interviews than students with lower GPAs. Students who meet the academic criteria set by the public accounting firms may elect to forego the campus interviews for personal reasons. On the other hand, students who lack the necessary credentials cannot request an interview and most likely would not be selected even if the accounting firm did not specify a GPA requirement. 
TABLE 2 Student Interviewing Experiences

\begin{tabular}{|c|c|c|c|c|}
\hline Panel A & $\begin{array}{c}\text { Total } \\
\text { Graduating } \\
\underline{\text { Class }}\end{array}$ & \multicolumn{2}{|c|}{$\begin{array}{c}\text { Participants } \\
\text { in } \\
\text { Study }\end{array}$} & $\begin{array}{c}\text { Non-Participants } \\
\text { in } \\
\underline{\text { Study }}\end{array}$ \\
\hline \multicolumn{5}{|l|}{ Number of students: } \\
\hline Student in graduating class & 127 & \multicolumn{2}{|c|}{106} & 21 \\
\hline Students without campus interviews & $(60)$ & \multicolumn{2}{|c|}{$(52)$} & $(8)$ \\
\hline Students selected for campus interviews & 67 & \multicolumn{2}{|c|}{54} & $\overline{13}$ \\
\hline Campus interview requests & 1201 & \multicolumn{2}{|c|}{ N/A } & N/A \\
\hline Campus interviews granted & 401 & \multicolumn{2}{|c|}{299} & 102 \\
\hline \multicolumn{5}{|l|}{ Panel B } \\
\hline & $\underline{\text { Total }}$ & $\begin{array}{c}\text { "Prime" } \\
\text { Candidates }\end{array}$ & $\begin{array}{l}\text { "Average" } \\
\text { Candidates }\end{array}$ & $\begin{array}{c}\text { "Poor" } \\
\text { Candidates } \\
\end{array}$ \\
\hline \multicolumn{5}{|l|}{ Number of Students: } \\
\hline Students in graduating class & 127 & N/A & N/A & N/A \\
\hline Students not participating in study & $\underline{(21)}$ & $\underline{\mathrm{N} / \mathrm{A}}$ & $\underline{\mathrm{N} / \mathrm{A}}$ & $\underline{\mathrm{N} / \mathrm{A}}$ \\
\hline Students participating in study & $\overline{106}$ & $\overline{19}$ & $\overline{50}$ & $\overline{37}$ \\
\hline Students participating in study, but no interviews & $\underline{(52)}$ & (3) & $(24)$ & $(25)$ \\
\hline Students participating in study with interviews & $\overline{54}$ & $\overline{16}$ & 26 & $\overline{12}$ \\
\hline \multicolumn{5}{|l|}{$\begin{array}{l}\text { Interview experience of } 54 \text { participating students } \\
\text { by firm type: }\end{array}$} \\
\hline National firms & 110 & 52 & 49 & 9 \\
\hline Regional firms & 64 & 28 & 34 & 2 \\
\hline Local firms & $\underline{125}$ & $\underline{40}$ & $\underline{70}$ & $\underline{15}$ \\
\hline Total number of interviews & $\overline{299}$ & $\overline{120}$ & $\overline{153}$ & $\overline{26}$ \\
\hline Average number of interviews per participant & 5.5 & 7.5 & 5.8 & 2.2 \\
\hline
\end{tabular}

N/A - data not available

A total of 401 on-campus interviews were conducted, of which 299 (75 percent) were with students who participated in the study. As illustrated in TABLE 2(Panel B), students participating in the study who were categorized as "prime candidates" were the most successful in securing an on-campus interview (mean=7.5 interviews), and those identified as "poor candidates" were the least successful (mean=2.2 interviews). Data concerning the outcomes of the campus interviews and follow-up office interviews, if any, were not available.

\section{Recruiters}

Sixty-three recruiters participated in the study. Table 3 reports the demographic profile of the recruiter group. Although certain aspects of the group are noteworthy, the respondents were considered representative of the public accounting firm recruiters.

First, the gender mix of the recruiter group is not balanced. Three times as many males than females participated in the study. The absence of female recruiters is consistent with the experiences reported by Scott et al.(1985) and Lathan et al.(1987). ANOVA of the recruiter responses by gender was performed to test for a possible bias in the data due to the group's gender mix. No systematic differences were noted between the responses of the male and female recruiters.

A second area of difference is the representation by firm type and office size. The group included a large proportion of recruiters from local firms and smaller offices. The composition of the group can be attributed to two factors. First, several of the national firms have merged. This resulted in the consolidation of several Big-4 local offices and a corresponding decline in the absolute number of personnel associated with the recruiting function. Second, the school's accounting department had undertaken a program to increase the number of accounting firms 
recruiting on campus. These efforts significantly increased the number of firms, primarily local firms, and recruiting on-campus.

TABLE 3 Recruiter Characteristics

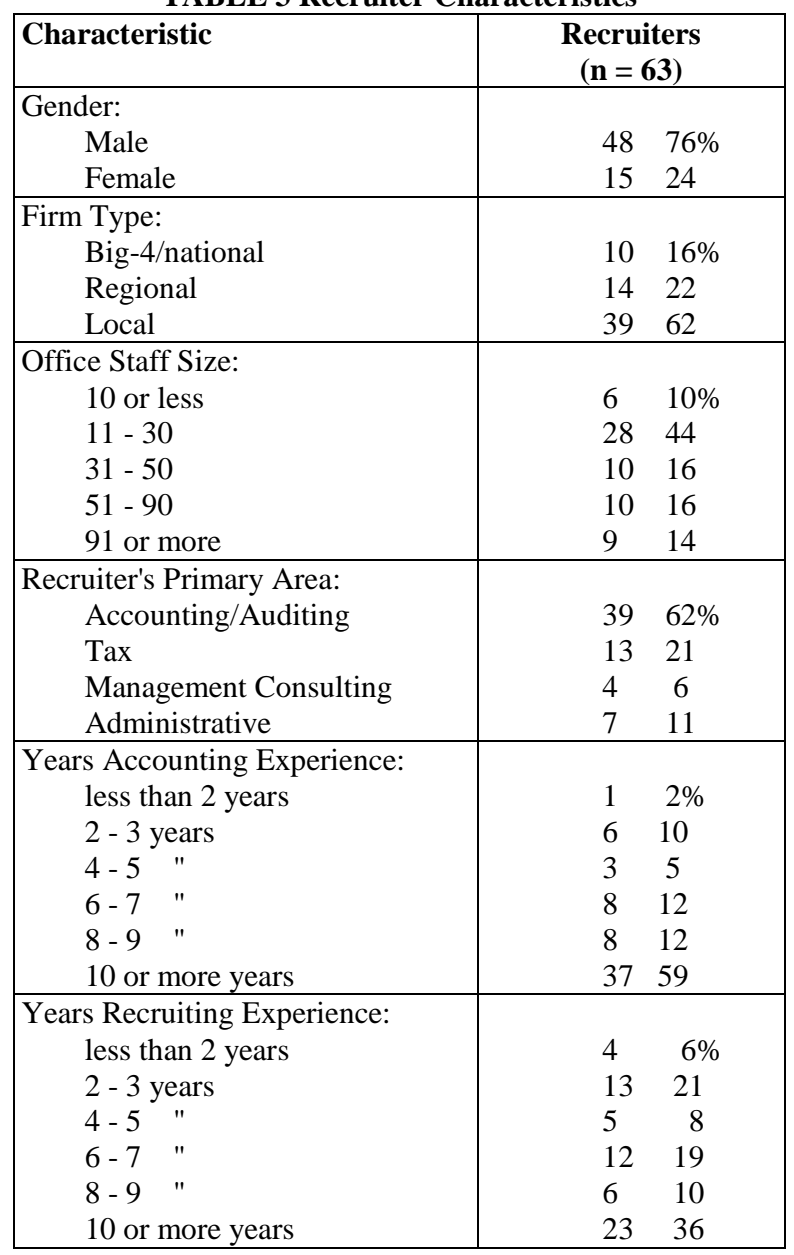

Third, the recruiter group includes a slightly more experienced set of recruiters. Due to the anonymity of the survey process, specific respondents could not be identified. However, a number of the contact firm personnel in the survey had been recruiting at the campus for well over 10 years. ANOVA of the recruiter responses by years of recruiting experience was performed to test for a possible bias in the data due to recruiting experience. No systematic differences were noted among the recruiters by years of recruiting experience.

\section{Question \#1 Do students' opinions vary by their recruitability status?}

When the students were grouped by their recruitability status, the analysis did not reveal any consistent pattern of response differences across the six sets of employer characteristics (Table 4). Only two statistically significant differences were noted ("traveling on personal time" and "the variety of clients"). In both instances, the "prime candidates" attached the greatest importance to the employer characteristic. As each difference related to a different set of employer characteristics, the student recruitability groups were combined and evaluated as a single group for subsequent analyses. 
TABLE 4 Student Mean Importance Ratings for Employer Characteristics, By Student Recruitability Status

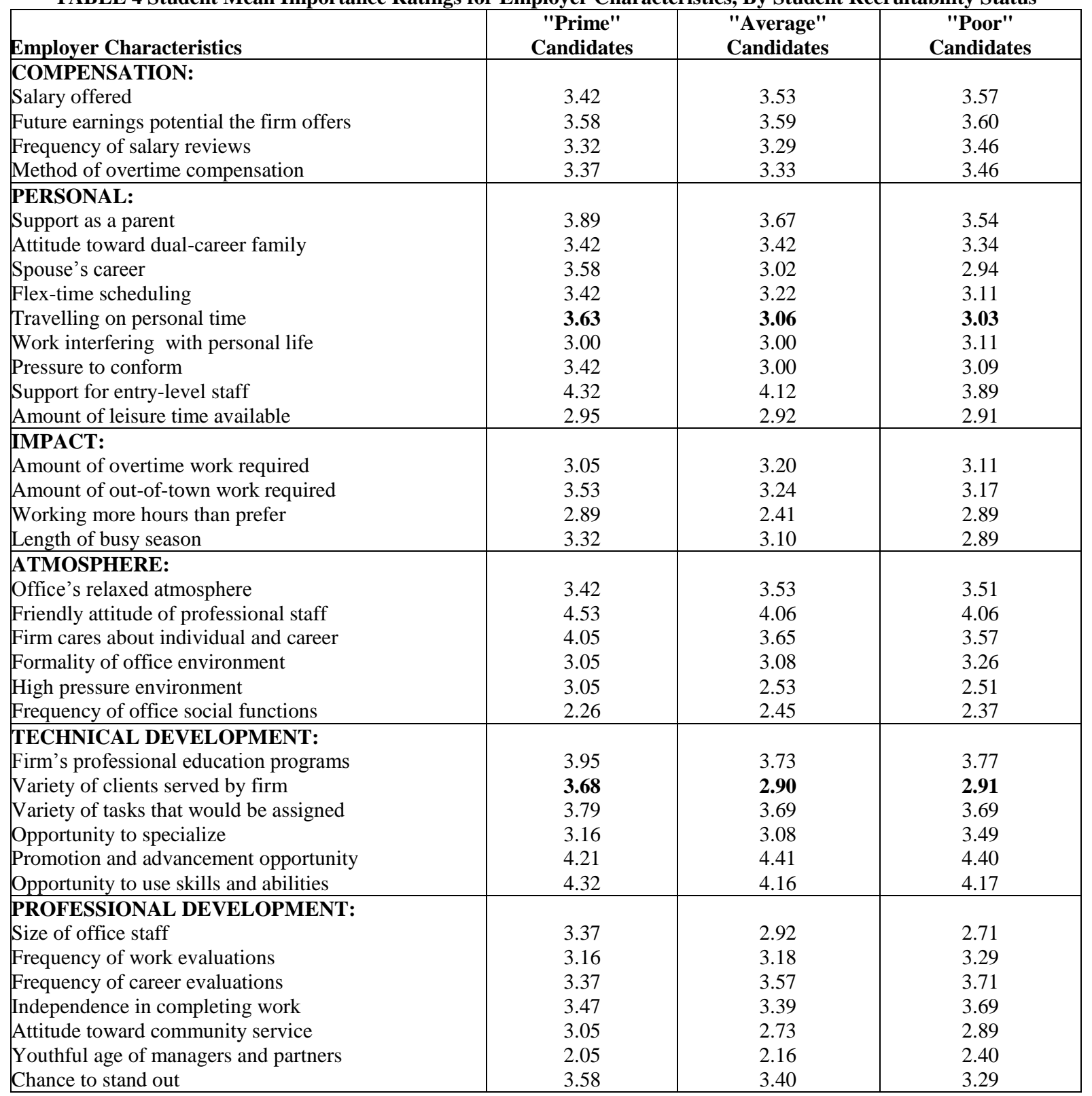

Bold_ $=$ statistically significant difference $(p<0.05), 1=$ not important, $\ldots, 5=$ extremely important

\section{Question \#2 What is the structure of the recruiting interview?}

Analysis of the recruiter responses indicated a consistent pattern in the level of discussion afforded selected firm characteristics during the interview process (Table 5). In general, recruiters focused their discussion on characteristics associated with Technical Development and Professional Development while the characteristics related to Personal and Compensation receive relatively little discussion. Atmosphere and Impact characteristics were discussed, but at lower levels than the technical and professional development characteristics. Collectively, the recruiters provide relatively less discussion of the matters that may be considered "quality of life" issues or that may affect the student's ability to balance personal and professional lives. 
TABLE 5 Recruiter Mean Level of Discussion Ratings for Employer Characteristics

\begin{tabular}{|c|c|}
\hline Employer Characteristics & $\begin{array}{c}\text { Recruiters } \\
n=63\end{array}$ \\
\hline \multicolumn{2}{|l|}{ COMPENSATION: } \\
\hline Salary offered & 2.03 \\
\hline Future earnings potential firm offers & 1.60 \\
\hline Frequency of salary reviews & 2.75 \\
\hline Method of overtime compensation & 2.76 \\
\hline \multicolumn{2}{|l|}{ PERSONAL: } \\
\hline Support as a parent & 2.25 \\
\hline Attitude toward dual career family & 1.74 \\
\hline Spouse's career & 1.41 \\
\hline Flex time scheduling & 2.47 \\
\hline Traveling on personal time & 2.15 \\
\hline Work interfering with personal life & 2.13 \\
\hline Pressure to conform & 1.34 \\
\hline Support for entry-level staff & 3.30 \\
\hline Amount of leisure time available & 1.95 \\
\hline \multicolumn{2}{|l|}{ IMPACT: } \\
\hline Amount of overtime work required & 3.40 \\
\hline Amount of out-of-town work required & 3.06 \\
\hline Working more hours than prefer & 2.37 \\
\hline Length of busy season & 3.02 \\
\hline \multicolumn{2}{|l|}{ ATMOSPHERE: } \\
\hline Office's relaxed atmosphere & 3.06 \\
\hline Friendly attitude of professional staff & 3.43 \\
\hline Firm cares about individual and career & 3.03 \\
\hline Formality of office environment & 2.25 \\
\hline High pressure environment & 2.87 \\
\hline Frequency of office social functions & 2.33 \\
\hline \multicolumn{2}{|l|}{ TECHNICAL DEVELOPMENT: } \\
\hline Firm's professional education programs & 3.67 \\
\hline Variety of clients served by firm & 3.73 \\
\hline Variety of tasks that would be assigned & 4.03 \\
\hline Opportunity to specialize & 3.35 \\
\hline Promotion and advancement opportunity & 3.75 \\
\hline Opportunity to use skills and abilities & 3.52 \\
\hline \multicolumn{2}{|l|}{ PROFESSIONAL DEVELOPMENT: } \\
\hline Size of office staff & 3.00 \\
\hline Frequency of work evaluations & 3.10 \\
\hline Frequency career evaluations & 3.16 \\
\hline Independence in completing work & 2.94 \\
\hline Attitude toward community service & 3.16 \\
\hline Youthful age of managers and partners & 2.16 \\
\hline Chance to stand out & 2.40 \\
\hline
\end{tabular}

\section{Question \#3 Do recruiting interviews vary by firm size?}

ANOVA and Scheffe' analyses of recruiter responses grouped by firm size identified statistically significant differences within five of the six sets of employer characteristics (Table 6). No significant differences exist regarding the compensation characteristics. Analyses of the nine characteristics included in the personal set identified significant differences on four variables. In each case, the national recruiters reported a greater level of discussion than the recruiters representing smaller sized firm recruiters. With the exception of "flex scheduling", the responses of the regional and local firm recruiters were similar. 
TABLE 6 Comparison of Recruiter Mean Level of Discussion Ratings for Employer Characteristics (Recruiters Grouped by Firm Size)

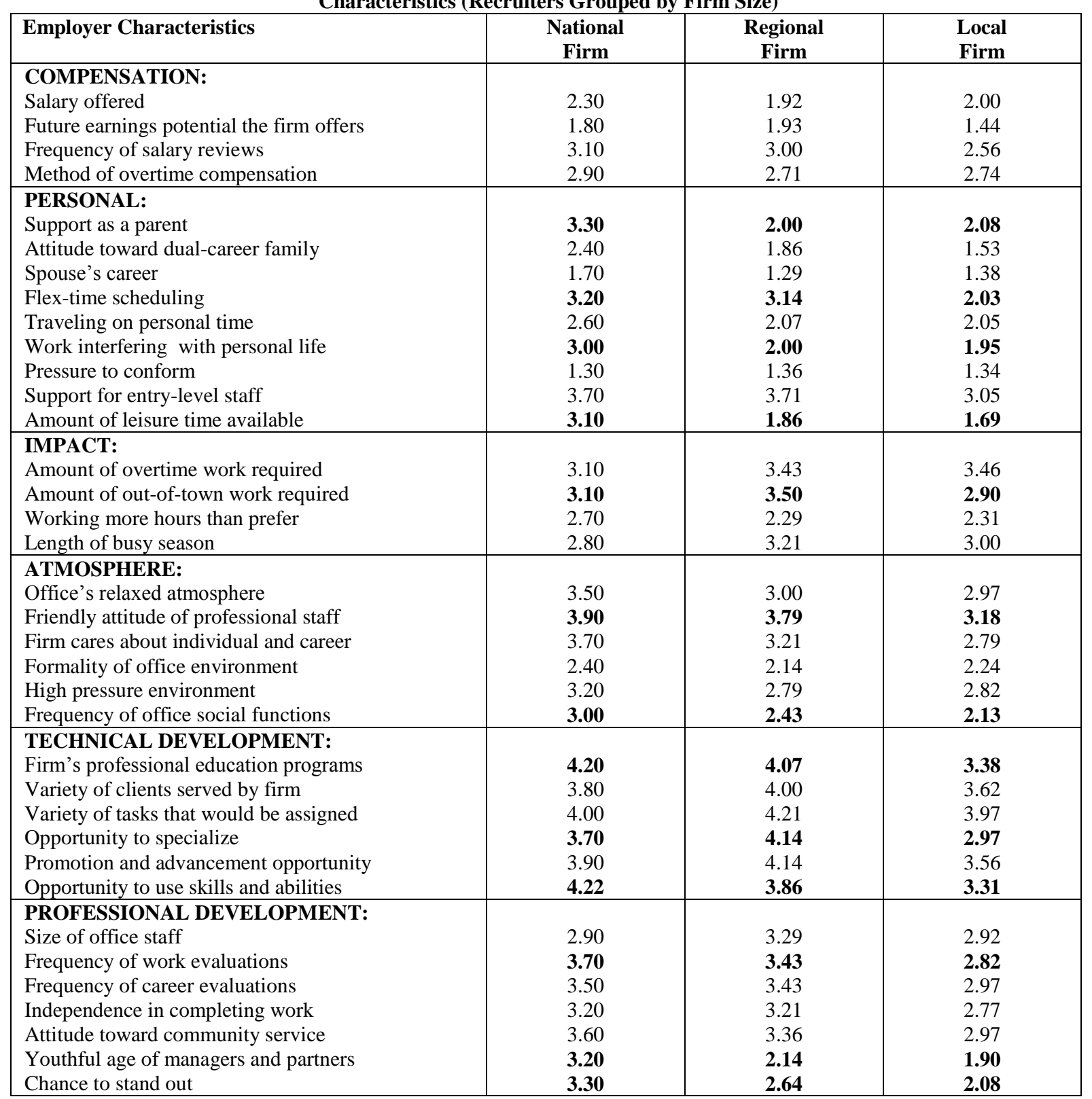

Bold = statistically significant difference $(p<0.05), 1=$ do not mention, $\ldots, 5=$ lengthy discussion

One significant difference exists within the impact characteristic set. The difference related to the "amount of out-of-town work" required characteristic. In this case, the regional firm reported the highest level of discussion.

Analysis of the atmosphere set of characteristics indicated two significant differences. One relates to the "friendly attitude of the professional staff" and the other to the "frequency of office social functions." In both cases, the level of discussion by the national firm recruiters is greater than that provided by recruiters from the local firms. The regional firm recruiter responses are statistically similar to both the national and local firm recruiters. 
The recruiters also differed on the technical development characteristics. Differences are noted on three of the six employer characteristics. In two cases ("professional education programs" and "the opportunity to use skills and abilities"), the national firm recruiters indicate a higher level of discussion than the local firm recruiters do. The level of discussion by the regional firm recruiters is not significantly different from that of either the national or local firm recruiters. The third difference related to the opportunity to specialize. In this case, the recruiters from the regional firms reported the highest level of discussion and the responses of the national and local firm recruiters were similar.

The recruiter groups differed on three of the seven professional development characteristics. Consistent across the three characteristics, the national firm recruiters report a greater level of discussion about "the frequency of work evaluations", "the youthful age of managers and partners", and "the chance to stand out." The levels of discussion by the regional and local firm recruiters are not statistically different.

\section{Question \#4 Which sized firms are meeting student information needs?}

In terms of meeting student informational needs, the national firm recruiters were the most successful, regional firm recruiters were somewhat comparable to the national firms, and the local firm recruiters were the least successful (TABLE 7). Success is defined here as the consistency between the recruiters' level of discussion of an employer characteristic and the level of importance students assigned the characteristic.

Analyses of the responses of the students and each recruiter group along the four characteristics associated with the compensation set showed statistically significant differences. National firm recruiters had the fewest differences (two) and the local firm recruiters the greatest number of differences (four). Consistent across the recruiter groups, the level of recruiter discussion for each of these four items was statistically lower than the importance attached by the students.

Analyses identified statistical differences between students and each recruiter group among the nine employer characteristics embodied in the personal set. National firm recruiters had the fewest differences (four characteristics) while local firm recruiters had the most (all nine characteristics). Consistent across the recruiter groups, students assigned greater importance to these employer characteristics than the reported level of discussion by the recruiters.

Only one statistically significant difference was identified between student importance ratings and recruiter levels of discussion among the characteristics associated with the IMPACT set. In this case, the local firm recruiter discussion of "the amount of out-of-town work required" was less than the students' perception of the characteristic's importance.

Analyses of the student and local firm recruiter responses to the employer characteristics associated with the atmosphere set identified significant differences among the variables. Again the level of discussion by the national firm recruiters most closely matched the importance assigned by the students (only one statistically significant difference noted). The local firm recruiters had the greatest number of differences (four). In each case of a significant difference, the recruiter level of discussion was below the importance assigned to the characteristic by the students.

The response pattern between the student and recruiter groups over the characteristics associated with the technical development and professional development sets were consistent with those noted along the other four sets of characteristics. Discussion ratings from the national firm recruiters showed the fewest differences from the student importance scores, while the local firm recruiter ratings had the greatest number of differences.

Within the set of technical development characteristic, all recruiter groups consistently reported higher levels of discussion than student importance ratings. The exceptions were the local recruiter discussion of "professional education programs" and "the opportunity to use one's skills and abilities." In each case, the recruiters reported a level of discussion below the importance that students assigned the characteristic. 
On the other hand, within the set of professional development characteristics, the recruiters consistently reported lower levels of discussion than the student importance ratings. The two exceptions were the national firm recruiters reported greater discussion of characteristics concerning "community service" and "the youthful ages of managers and partners" than the student importance scores.

\section{DISCUSSION}

This study assessed the importance that students attach to various employer qualities and the extent that public accounting recruiters discuss such qualities during the process of interviewing for entry-level staff. The study focused on attitudinal differences among students with varying academic credentials as well as differences in the content of recruiting interviews by various sized public accounting firms. The study also assessed the extent that the interviews of various sized public accounting firms met the informational needs of students.

Students, regardless of their "recruitability status" tended to attach the same importance to employer characteristics. Students consistently assigned greater importance to certain employer characteristics. As a group, matters associated with the development of technical skills and abilities are the most-valued characteristics. Students also consider compensation matters (both current and future) to be important employer characteristics. On the other hand, students assign relatively less importance to employer features that would affect or influence their professional development and the time commitments that the work may impose. Accordingly, recruiters may want to reconsider the structure of their interviews with candidates of different genders or ages (based on prior research), but the student's academic credentials should not influence the content of the interview.

Collectively, the student responses represent matters of significance to public accounting firms. Students recognize the nature of the public accounting work environment, see it as an opportunity to develop certain skill sets, but are not necessarily concerned about factors that are be associated with a long-term career in public accounting. While in public practice, however, students expect to be well compensated.

With such a perception or mindset among students, public accounting firms can expect not only a continuation of personnel problems at the entry-level but also staffing pressures to worsen at the senior and supervisory levels. Future research may want to explore where and how students develop their employer expectations and why public accounting is only viewed as a stepping stone rather than a professional career.

The content that the recruiter brings to the interview relates to what many perceive as two of the major problems facing the profession: compensation matters and resources or opportunities for the staff to balance their personal and professional lives. Student responses in this study suggest that these issues are not adequately discussed during the recruiting process. These shortcomings reflect institutional barriers that should be addressed as part the profession's long-term solution to its staffing needs.

Public accounting starting salaries have not kept pace with competing career opportunities available to accounting students (Albrecht \& Sack, 2000). Starting salaries must rise to competitive levels that reflect the additional educational investment students are being asked to make. Public accounting firms, however, must not only adjust entry-level salaries upward but also devise compensation plans that remain competitive throughout a staff member's professional career.

At the same time, the profession must work to create an environment that meets the personal needs of the changing face of the work force and is supportive over the span of a professional career. Students are interested in those firm features that meet the need to find balance between personal and professional lives as well as the demands that are associated with dual-career couples. Future research may want to investigate alternative work environments and personnel policies that would address the personal needs of the staff while allowing the public accounting firm to fulfill its client responsibilities.

The structure of the recruiting interview was found in this study to vary across public accounting firms of differing sizes. The consistent response pattern in those areas where the firms differed was that the national public 
accounting firms had a higher level of discussion. One possible explanation may be the desire of the national firms to better differentiate themselves as a career option.

The national firm interviews included more discussion of personal and professional and technical development matters. The national firm recruiters may be attempting to overcome any negative perceptions held by students due to the high staff turnover rates and the demands often associated with the larger firms. For example, a recent series of articles in a student-oriented publication presented the national accounting firms in a less-thanfavorable light (Satava, 1999a; 1999b; \& 2000).

In terms of meeting student information needs, the interviews of the national public accounting firm were the most successful and those of the local firms were the least. Where differences were noted between student interest and recruiter discussion, the recurring pattern was the failure of recruiters to raise the level of discussion consistent with the importance attached by students. As the firm size decreased, the disparity between student importance ratings and recruiter discussion levels increased not only in absolute number but also in degree. The recruiters from the smaller firms grossly under-discussed certain firm characteristics that are perceived to be important by students.

The differences among the recruiters from the various sized firms may be due to how the recruiters view the interview. Recruiters from the larger firms may consider the recruiting interview more from a seller perspective. They are confident in their prescreening and candidate selection criteria and consider the interview more as an opportunity to market the firm than to select a candidate.

Respondents from the smaller firms, on the other hand, may only see the interview from a buyer's perspective. Because the smaller firms attract fewer of the prime student candidates, the recruiter must allow more interview time to identifying candidates who will meet the firm's needs. This results in less interview time available for marketing the firm to the student as a career option.

\section{LIMITATIONS}

Due to certain limitations inherent in the study's design and methodology, any attempt to generalize its findings should be done with caution. First, the data were collected from available pools of students and recruiters rather than through random selection procedures. Second, the student and recruiter groups respectively represented one university and the mid-western locale. The recruiting process may vary from that found at other institutions. For example, schools with more developed internship programs may find the recruiting process beginning prior to the senior year. Third, the study was performed in a state in which the 150-hour education requirement was not yet in effect. The recruiting process and student attitudes may vary in other jurisdictions. Fourth, the employer characteristics evaluated may not capture all the variables entering into the recruiting decision-making process. Fifth, differences may exist between the importance that students assigned the firm characteristics and their influence in actual recruiting decisions. Sixth, the study's design and methodology did not address the credibility of the matters discussed by recruiters during the recruiting process.

This project was supported by grants provided by the Department of Accounting and the College of Business. A copy of the survey data may be obtained from the author upon request. 
TABLE 7 Comparison of Mean Student Importance Ratings and Mean Recruiter Level of Discussion Ratings (Recruiters Grouped by Firm Size)

\begin{tabular}{|c|c|c|c|c|}
\hline Employer Characteristics & Students & $\begin{array}{c}\text { Recruiters } \\
\text { National Firm }\end{array}$ & $\begin{array}{c}\text { Recruiters } \\
\text { Regional Firm }\end{array}$ & $\begin{array}{l}\text { Recruiters } \\
\text { Local Firm }\end{array}$ \\
\hline $\begin{array}{l}\text { COMPENSATION: } \\
\text { Salary offered } \\
\text { Future earnings potential the firm offers } \\
\text { Frequency of salary reviews } \\
\text { Method of overtime compensation } \\
\end{array}$ & $\begin{array}{l}3.53 \\
3.61 \\
3.36 \\
3.39 \\
\end{array}$ & $\begin{array}{l}\mathbf{2 . 3 0} \\
\mathbf{1 . 8 0} \\
3.10 \\
2.90 \\
\end{array}$ & $\begin{array}{l}1.92 \\
1.93 \\
3.00 \\
2.71 \\
\end{array}$ & $\begin{array}{l}2.00 \\
1.44 \\
2.56 \\
2.74 \\
\end{array}$ \\
\hline $\begin{array}{l}\text { PERSONAL: } \\
\text { Support as a parent } \\
\text { Attitude toward dual-career family } \\
\text { Spouse's career } \\
\text { Flex-time scheduling } \\
\text { Traveling on personal time } \\
\text { Work interfering with personal life } \\
\text { Pressure to conform } \\
\text { Support for entry-level staff } \\
\text { Amount of leisure time available }\end{array}$ & $\begin{array}{l}3.67 \\
3.38 \\
3.08 \\
3.24 \\
3.18 \\
3.05 \\
3.10 \\
4.09 \\
2.92 \\
\end{array}$ & $\begin{array}{l}3.30 \\
2.40 \\
1.70 \\
3.20 \\
2.60 \\
3.00 \\
1.30 \\
3.70 \\
3.10 \\
\end{array}$ & $\begin{array}{l}2.00 \\
1.86 \\
1.29 \\
3.14 \\
2.07 \\
2.00 \\
1.36 \\
3.71 \\
1.86\end{array}$ & $\begin{array}{l}2.08 \\
1.53 \\
1.38 \\
2.03 \\
2.05 \\
1.95 \\
1.34 \\
3.05 \\
1.69\end{array}$ \\
\hline $\begin{array}{l}\text { IMPACT: } \\
\text { Amount of overtime work required } \\
\text { Amount of out-of-town work required } \\
\text { Working more hours than prefer } \\
\text { Length of busy season }\end{array}$ & $\begin{array}{l}3.16 \\
3.27 \\
2.65 \\
3.09 \\
\end{array}$ & $\begin{array}{l}3.10 \\
3.10 \\
2.70 \\
2.80 \\
\end{array}$ & $\begin{array}{l}3.43 \\
3.50 \\
2.29 \\
3.21 \\
\end{array}$ & $\begin{array}{l}3.46 \\
\mathbf{2 . 9 0} \\
2.31 \\
3.00 \\
\end{array}$ \\
\hline $\begin{array}{l}\text { ATMOSPHERE: } \\
\text { Office's relaxed atmosphere } \\
\text { Friendly attitude of professional staff } \\
\text { Firm cares about individual and career } \\
\text { Formality of office environment } \\
\text { High pressure environment } \\
\text { Frequency of office social functions }\end{array}$ & $\begin{array}{l}3.52 \\
4.16 \\
3.70 \\
3.14 \\
2.62 \\
2.39\end{array}$ & $\begin{array}{l}3.50 \\
3.90 \\
3.70 \\
2.40 \\
3.20 \\
3.00\end{array}$ & $\begin{array}{l}\mathbf{3 . 0 0} \\
3.79 \\
3.21 \\
\mathbf{2 . 1 4} \\
2.79 \\
2.43\end{array}$ & $\begin{array}{l}2.97 \\
3.18 \\
2.79 \\
2.24 \\
2.82 \\
2.13\end{array}$ \\
\hline $\begin{array}{l}\text { TECHNICAL DEVELOPMENT: } \\
\text { Firm's professional education programs } \\
\text { Variety of clients served by firm } \\
\text { Variety of tasks that would be assigned } \\
\text { Opportunity to specialize } \\
\text { Promotion and advancement opportunity } \\
\text { Opportunity to use skills and abilities }\end{array}$ & $\begin{array}{l}3.78 \\
3.01 \\
3.70 \\
3.23 \\
4.39 \\
4.18 \\
\end{array}$ & $\begin{array}{l}4.20 \\
\mathbf{3 . 8 0} \\
4.00 \\
3.70 \\
\mathbf{3 . 9 0} \\
4.22 \\
\end{array}$ & $\begin{array}{l}4.07 \\
\mathbf{4 . 0 0} \\
\mathbf{4 . 2 1} \\
\mathbf{4 . 1 4} \\
4.14 \\
3.86 \\
\end{array}$ & $\begin{array}{l}\mathbf{3 . 3 8} \\
\mathbf{3 . 6 2} \\
3.97 \\
2.97 \\
\mathbf{3 . 5 6} \\
\mathbf{3 . 3 1}\end{array}$ \\
\hline $\begin{array}{l}\text { PROFESSIONAL DEVELOPMENT: } \\
\text { Size of office staff } \\
\text { Frequency of work evaluations } \\
\text { Frequency of career evaluations } \\
\text { Independence in completing work } \\
\text { Attitude toward community service } \\
\text { Youthful age of managers and partners } \\
\text { Chance to stand out }\end{array}$ & $\begin{array}{l}2.91 \\
3.19 \\
3.56 \\
3.51 \\
2.83 \\
2.21 \\
3.40\end{array}$ & $\begin{array}{l}2.90 \\
3.70 \\
3.50 \\
3.20 \\
\mathbf{3 . 6 0} \\
\mathbf{3 . 2 0} \\
3.30\end{array}$ & $\begin{array}{l}3.29 \\
3.43 \\
3.43 \\
3.21 \\
3.36 \\
2.14 \\
\mathbf{2 . 6 4}\end{array}$ & $\begin{array}{l}2.92 \\
\mathbf{2 . 8 2} \\
\mathbf{2 . 9 7} \\
\mathbf{2 . 7 7} \\
2.97 \\
1.90 \\
\mathbf{2 . 0 8}\end{array}$ \\
\hline
\end{tabular}

Bold_= statistically significant difference $(p<0.05)$ between recruiter subgroup and students

Students: $1=$ not very important, .., 5 =extremely important

Recruiters: $1=$ do not mention, ..., $5=$ lengthy discussion

\section{REFERENCES}

1. Accounting Education Change Commission (AECC). (1993). "Improving the early employment experience of Accountants: Issues statement no. 4". Issues in Accounting Education, 8(2), 431-435.

2. Albrecht, W.S., \& Sack, R. J. (2000). Accounting Education: Charting the Course through a Perilous Future. Sarasota, FL: American Accounting Association. 
3. Alderfer, C. P. (1972). Existence, Relatedness and Growth: Human Needs in Organizational Settings. New York, NY: Free Press.

4. American Accounting Association (AAA). "Practice Involvement Committee of the Administrators of Accounting Programs. (1995). Accounting faculty/practitioners partnership to address mutual educational concerns". Issues in Accounting Education, 10(1), 97-206.

5. Arthur Andersen \& Co., Ernst \& Whinney, Arthur Young, Peat Marwick Main \& Co., Coopers \& Lybrand, Price Waterhouse, Deloitte Haskins \& Sells, \& Touche Ross. (1989). Perspectives on Education: Capabilities for Success in the Accounting Profession.

6. Beard, V. (1998). "Understanding student dissatisfaction with campus recruiting". The Accounting Educator, 10(2), 29-43.

7. Carcello, J. V., Copeland, J. E., Hermanson, R. H., \& Turner, D. H. (1991). "A public accounting career: the gap between student expectations and accounting staff experiences". Accounting Horizons, 5(3), 1-11.

8. Collins, S. H. (1987). "Recruiting and retaining the best and the brightest in today's economic market". Journal of Accountancy, 163(2), 52-52.

9. Covaleski, J. M. (1999). "Fee growth stunted by staffing shortages". Accounting Today, 13(14), 1, 46.

10. Craig, J. L. (1990). "Recruiting at small and medium-sized CPA firms: A panel discussion with representatives of six firms". The CPA Journal, LX (9), 14-20.

11. DeZoort, F. T., Lord, A. T., \& Cargile, B. R. (1997). "A comparison of accounting professors' and students' perceptions of the public accounting work environment". Issues in Accounting Education, 12(2), 281-298.

12. Dinius, S. H., \& Rogow, R. B. (1988). "Application of the Delphi method in identifying characteristics big eight firms seek in entry-level accountants". Journal of Accounting Education, 6, 83-101.

13. Donelan, J. G. (1999). "The 150-hour education requirement: implications for recruiting accounting graduates". The Ohio CPA Journal, October - December 41-44.

14. Duncan, J. R., \& Schmutte, J. (2000). “Accounting internships and the 150-hour requirement”. Working paper, Ball State University.

15. Fein, R., \& Krzystofik, A. T. (1989). "Student views toward the on-campus recruiting process". The CPA Journal, LIX (8), 54-56.

16. Fuller, J. (1998). "Booming economy sends firms scrambling for staff". Accounting Today, 12(11), 3-4.

17. Garner, R. M., Dombrowski, R. F., \& Perdue, F. P. (1993). "Recruiting future CPAs: is enough being done" Journal of Accountancy, 176(6), 16.

18. Hermanson, R. H., Carcello, J. V., Hermanson, D. R., Milano, B. J., Polansky, G. A., \& Williams, D. Z. (1995). "Better environment, better staff". Journal of Accountancy, 179(4), 39-44.

19. Higgins, J. J. (1989). Interviewing for a career in public accounting. Rochester, MI: Hampton Press.

20. Kochanek R. F., \& Norgaard, C. T. (1985). "Student perceptions of alternative accounting careers - part II". The CPA Journal, LIV (6), 26-29.

21. Larkin, J. M., \& Ragan, J. M. (1991). "How new hires choose among CPA firms". The Ohio CPA, November-December, 23-30.

22. Lathan, M. H., Ostrowski, B. A., Pavlock, E. J., \& Scott, R. A. (1987). "Recruiting entry level staff: gender differences". The CPA Journal, LVII (1), 31-42.

23. McMillan, J. J., Ryan, D. H., \& Salter, S. B. (1994)."Enhancing communication during the recruiting process: the views of accounting students and accounting recruiters". Advances in Accounting, 12(1). Greenwich, CN: JAI Press Inc.

24. Meeting, D. T. and Bakale, A. S. (1996). "Recruiting the best and brightest: a guide for local and regional firms". The Ohio CPA Journal, April, 41-42.

25. Morgan, R. B., \& Smith, J. E. (1996). Staffing the New Workplace: Selecting and Promoting for Quality Improvement. Milwaukee, WI: ASQC Quality Press.

26. Nelson, A. T. (1989). "The human resource dilemma in accounting". Journal of Accounting, 168(2), 46-52.

27. Nelson, I. T., \& Vendrzyk, V. P. (1996). "Trends in accounting student characteristics: a longitudinal study at FSA schools", 1991-95. Journal of Accounting Education, 14(4), 453-475.

28. Pasewark, W. R., Strawser, J. R., \& Wilkerson, J. E. (1988). "Empirical evidence on the association between characteristics of graduating accounting students and recruiting decisions of accounting employers". Issues in Accounting Education, 3(2), 388-401. 
29. Porter, L. W., Lawler III, E. E., \& Hackman, J. R. (1975). Behavior in Organizations. New York, NY: McGraw-Hill Book Company.

30. Posner, B. Z. (1981). "Comparing recruiter, student, and faculty perceptions of important applicant and job characteristics". Personnel Psychology, 34, 329-339.

31. Reed, S. A., \& Kratchman, S. H. (1989). "A longitudinal and cross-sectional study of students' perceptions of the importance of job attributes". Journal of Accounting Education, 7(2), 171-193.

32. Reigle, D., \& Meinert, J. (1991). "Attracting the best candidates". Journal of Accountancy, 172(4), 42-43.

33. Rosenberg, M. L., \& Nadolny, P. R. (1995). CPA Firm Administration Handbook. New York, NY: John Wiley \& Sons, Inc.

34. Rosse, J., \& Levin, R. (1997). High-Impact Hiring: A Comprehensive Guide to performance-based Hiring. San Francisco, CA: Jossey-Bass Publishers.

35. Roth, P. G., \& Roth, P. L. (1995). "Reduce turnover with realistic job previews". The CPA Journal, LXV (9), 68-69.

36. Sanders, B. (1998). The Supply of Accounting Graduates And the Demand For Public Accounting Recruits - 1996. New York, NY: AICPA.

37. Satava, D. R. (1999a). "26 things you should know before working for a national accounting firm". New Accountant, 15(1), 18-22.

38. (1999b). "26 things you should know before working for a national accounting firm". New Accountant, 15(2), 10-16.

39. (2000). "26 things you should know before working for a national accounting firm". New Accountant, 15(3), 10-17.

40. Satterfield, M. (1991). "The six most common recruiting mistakes". Journal of Accountancy, 171(2), 97100 .

41. Scott, R. A., Pavlock, E. J., \& Lathan, M. H. (1985). “On-campus recruiting: the students speak up”. Journal of Accountancy, 159(1), 60-72.

42. Siegel, P. H. and Rigsby, J. T. (1988) "The relationship of accounting internships and subsequent professional performance". Issues in Accounting Education, 4(2), 423-432.

43. Telberg, R. (1999). "Top consultants to CPAs: wake up". Accounting Today, 13(2), 1, 38.

44. Wanous, J. P. (1992). Organizational Entry: Recruiting, Selection, Orientation, and Socialization of Newcomers, Second Edition. Reading, MA:Addison-Wesley Publishing Company.

45. Yunker, P. J., Sterner, J. A., \& Costigan, M. (1986)."Employment in accounting: a comparison of recruiter perceptions with student expectations". Journal of Accounting Education, 4(1), 95-112. 